Miller, D. S. \& Payne, P. R. (1962). F. Nutr. 78, 255.

Miller, D. S. \& Payne, P. R. (1963). F. theoret. Biol. 5, 1398.

Mitchell, H. H. (1923-4). F. biol. Chem. 58, 905.

Mitchell, H. H. \& Hamilton, T. S. (1949). J. biol. Chem. r78, 345.

Morrison, A. B., Sabry, Z. I. \& Campbell, J. A. (1962). Canad. F. Biochem. 40, I663.

Morrison, A. B., Sabry, Z. I., Gridgeman, N. T. \& Campbell, J. A. (I 963). Canad. J. Biochem. 41, 275.

Munro, H. N. (195I). Physiol. Rev. 31, 449.

Munro, H. N. (1963). In Mammalian Protein Metabolism. [H. N. Munro and J. B. Allison, editors.] London: Academic Press Inc.

Munro, H. N. \& Wikramanayake, T. W. (1954). F. Nutr. 52, 99.

Naismith, D. J. (1962). Y. Nutr. 77, 381 .

National Research Council (1963). Evaluation of Protein Quality. Publ. nat. Res. Coun. Wash, no. I 100.

Osborne, T. B. (1907). Publ. Carneg. Instn, no. 84 .

Osborne, T. B., Mendel, L. B. \& Ferry, E. L. (1919). F. biol. Chem. 37, 223.

Oser, B. L. (195 1). F. Amer. diet. Ass. 27, 396.

Snyderman, S. E., Holt, L. E. Jr., Dancis, J., Roitman, E., Boyer, A. \& Balis, M. E. (1962). Y. Nutr. 78,57 .

Summers, J. D. \& Fisher, H. (196I). F. Nutr. 75, 435.

Swendseid, M. E., Watts, J. H., Harris, C. L. \& Tuttle, S. G. (1961). F. Nutr. 75, 295.

Voit, E. (1930). Z. Biol. 72, 549.

Willcock, E. G. \& Hopkins, F. G. (1906). \%. Physiol. 35, 88.

Woodyatt, R. T. (192 I). Arch. intern. Med. $28,125$.

\title{
Nutrient interrelationships of the fatty acids
}

By J. M. R. Beveridge, Department of Biochemistry, Queen's University, Kingston, Ontario, Canada

Any attempt to discuss in a definitive manner the nutrient interrelationships of the fatty acids is seriously hampered owing to a variety of reasons. These substances have been fed in the free form or as the methyl, ethyl, or simple glyceryl esters and the effects observed have been taken to reflect those of the respective fats and oils in which these fatty acids occur. It is not known, however, to what extent the nutritive effects of these compounds can be equated with those of the same acid as a residue of a natural triglyceride. Adding to the complexities of this problem is the recent finding by Dhopeshwarkar \& Mead (1962) that, at least in the guinea-pig, there is an endogenous production of methyl esters of the fatty acids. Many of the experiments described in the literature have involved a comparative study of the nutritive properties of various fats and oils differing in their fatty acid composition. All too frequently research workers have attributed any nutritional effects observed to differences in concentration of a group of fatty acids or indeed of a single fatty acid, ignoring or at least discounting the possible influence of the other differences in fatty acid composition of the fats under study. In addition, the effects of the nonglyceride components have been almost completely overlooked by many investigators. Usually the experimental conditions permit well-founded conclusions on the nutritive effects of dietary fat, but only an intelligent guess can be made concerning the probable role of the component fatty acids. With these limitations and qualifications in mind, let us now turn to an examination of some of the reports in the literature on this subject. This presentation makes no pretence of being encyclopaedic, and certain well-established interrelationships will not be discussed. 
One of the most important of the interrelationships of the fatty acids is that which exists between linoleic and arachidonic acids, these being interchangeable in the diet to provide the body's need for them. When the diet is devoid of these components certain tissue and metabolic sequelae develop. These include dermal changes associated with increased permeability to water, decreased efficiency of utilization of food for growth, and changes in the fatty acid composition of the body tissues (Aaes-Jørgensen, I96r). These changes are an increase in the content of palmitoleic, tri-, penta-, and hexa-enoic acids and a decrease in that of linoleic and arachidonic acids (Nunn \& Smedley-MacLean, I938; Aaes-Jørgensen \& Holman, 1958). The significance between the alteration in fatty acid pattern and the tissue lesions has yet to be established.

The mechanism by which the body synthesizes arachidonate from linoleate has been elucidated by Mead and his colleagues (Mead, 1960). Although it has been long maintained that pyridoxine is required for or facilitates this conversion (Witten \& Holman, 1952), several groups of workers have recently reported that their data provide no support for this belief (Greenberg \& Moon, I961; Williams \& Scheier, 196r; Kirschman \& Coniglio, r96r; Söderhjelm, ı962; Johnston, Kopaczyk \& Kummerow, I96r).

The work of James and his colleagues (James, Lovelock \& Webb, I959) describing the incorporation of labelled acetate into linoleate by the blood cells of man has raised the possibility that at least some synthesis of linoleate can be effected by certain cells of the body. Similar findings were reported by Marks, Gellhorn \& Kidson (1960) and by Buchanan (1960), but they showed that the synthetic activity of the blood cells resided in the leucocytes and platelets. They found that the red blood cells were without effect in this process.

Another interrelationship involving fatty acids has to do with the action of vitamin $E$ in preventing the oxidative destruction of the essential fatty acids in vivo (Hove \& Harris, 1946). Intensive long-term studies performed on man by Horwitt (1960) also provide support for this view and indicate that the requirement for vitamin $\mathrm{E}$ is a function of the amount of linoleic acid in the diet. A number of years ago, when we were studying dietary factors involved in the development of acute liver damage in rats, we found that if all the fat was removed from the basal diet mortality due to acute hepatic injury was low (McLean \& Beveridge, 1952). After the animals had been on the fat-free diet for $2-3$ months, the addition of lard to the diet, however, caused death usually within 4 days and sometimes within $24 \mathrm{~h}$. The use of fractions derived from the lard indicated that the potent factor was in the unsaturated portion. Subsequently it was found that the addition of as little as $0.25 \%$ linoleic acid to the diet greatly accelerated the development of the lethal liver lesion, whereas saturated acids had no effect and oleic acid was intermediate in its action (Valberg, Young \& Beveridge, 1959). As Schwarz and his co-workers have demonstrated, this liver damage may also be prevented by the inclusion of only a few p.p.m. of selenium in the diet (Schwarz, Bieri, Briggs \& Scott, I957). This finding points to the existence of an interrelationship between unsaturated fatty acids and vitamin $\mathrm{E}$ on the one hand 
and selenium on the other, but to date the nature of these relationships remains unknown.

The requirement for essential fatty acids has been reported by Hauge \& Nicolaysen (I959) and by Holman \& Peifer (I960) to be increased by dietary cholesterol. An acceptable metabolic basis for this action has not been presented to date.

A feature of some interest which may have some bearing on the point just mentioned is the effect of relatively unsaturated vegetable oils in causing a decrease in plasma lipid levels when such an oil is introduced into a diet in place of a more saturated fat usually of animal origin (Kinsell, Partridge, Boling, Margen \& Michaels, 1952). There are at least three reasons that could be advanced to explain this result: (1) the removal of a hypercholesterolaemic factor in the animal fat, (2) the addition of a hypocholesterolaemic factor in the vegetable oil, (3) a combination of $I$ and 2.

In $1954^{-} 5$ we found that when butterfat was added to a fat-free diet in place of an equicaloric amount of carbohydrate, the plasma cholesterol level went up, whereas when maize oil was added to a fat-free diet at a level of $40 \%$ or more of calories there was a small but significant decrease in plasma cholesterol content (Beveridge, Connell \& Mayer, 1956). These results, therefore, indicated that the third of the three possibilities correctly described the situation.

The nature of these hyper- and hypo-cholesterolaemic factors has been the subject of considerable controversy ever since. Before discussing to what extent the fatty acid composition may account for these divergent properties, I should like to raise several pertinent questions. What is meant by the hypocholesterolaemic action of vegetable oils? Under what conditions can it or should it be measured? How great is the effect? Certainly it is not permissible to substitute a vegetable oil for an animal fat in the diet and attribute, as indeed a number of workers have done, the resulting decrease in plasma cholesterol to the introduction of the vegetable oil per se. In order to assess the effect of a fat or an oil on plasma cholesterol levels, it has been our practice to have individuals eat a fat-free diet until the cholesterol values have reached a plateau. The oil to be tested is then added to the diet in place of an equicaloric amount of carbohydrate. We have followed this experimental pattern with the co-operation of student volunteer subjects who, in experiments each of 16 days' duration, subsisted on a variety of homogenized diets compounded to a known composition. Recently we summed up some of the results obtained during the past few years and data pertinent to the points I have raised are shown in Fig. I.

It should be noted that the values found at day o are, in so far as diet affects the result, dependent upon the type of free-choice diet comprising the usual variety of foodstuffs. Only the figures for days 4, 8, I2 and I6 reflect the influence of the experimental diets. It should be noted that, when subjects were transferred to a diet providing $40 \%$ or more of calories from butterfat, there was no change in the mean plasma cholesterol value. Only 32 of the 328 subjects were continued on the high-butterfat diet but the mean value remained essentially the same. The plasma concentration of the $84 \mathrm{I}$ subjects transferred to a fat-free diet showed an average decrease of 53.4 $\mathrm{mg}$ cholesterol/100 $\mathrm{ml}$. The decrease observed under these circumstances was remarkably similar for groups of individuals, as is exemplified by the following 


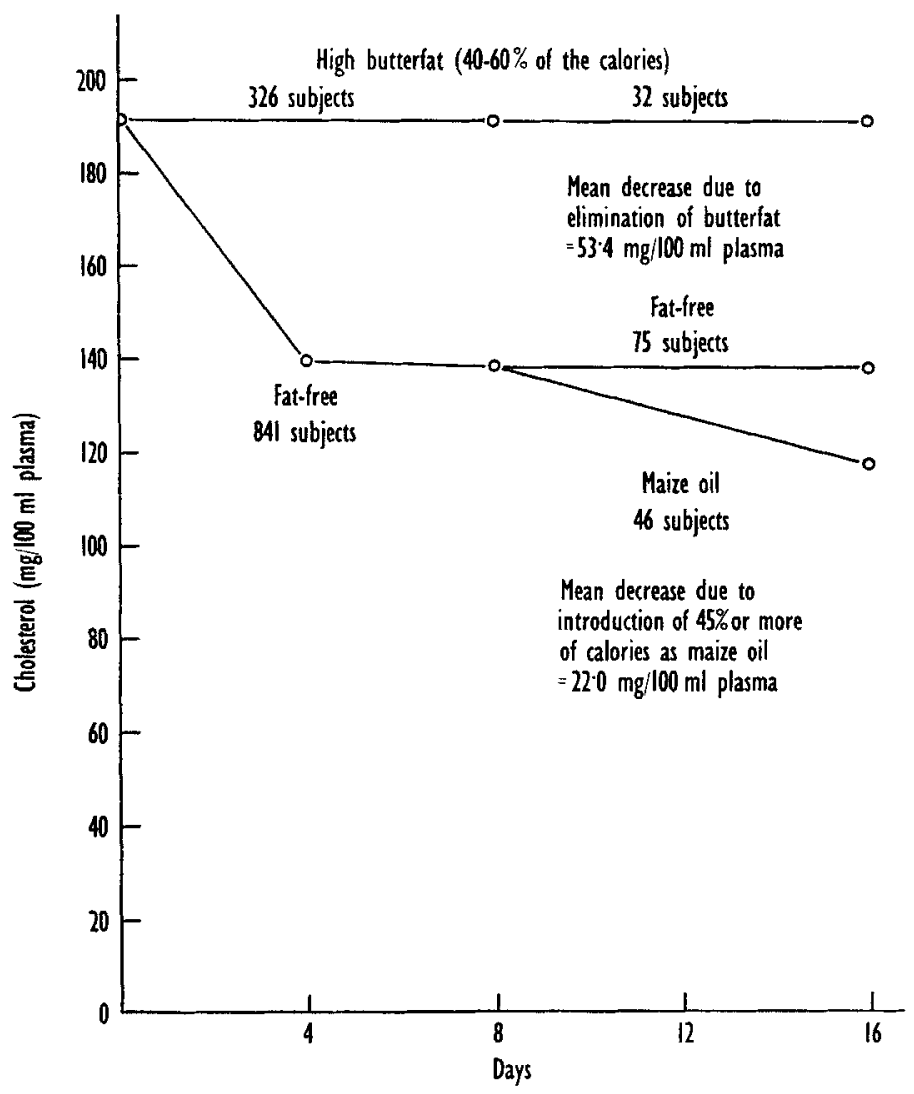

Fig. I. Mean plasma cholesterol values found in experiments performed over several ycars on student volunteers who consumed for 16-day periods homogenized compounded diets as shown.

figures showing the decreases obtained at day 8 in experiments performed at intervals over a period of several years: $54^{\cdot} \mathrm{x}, 57^{\cdot 8}, 52 \cdot 5,54 \cdot 2,47 \cdot 8,48 \cdot 0,49^{\circ} 8,55^{\circ} 7,54^{\cdot} \mathrm{I}$ and $52.6 \mathrm{mg} / 100 \mathrm{ml}$ plasma. When maize oil at a level to provide $45 \%$ or more of the calories was substituted for an equicaloric amount of carbohydrate, the fall in plasma cholesterol concentration amounted to between 16 and $26 \mathrm{mg} / \mathrm{r} 00 \mathrm{ml}$. In one experiment, however, it was only $3.1 \mathrm{mg}$, an insignificant change. The mean for the groups, excluding this one aberrant value, was $22 \mathrm{mg} / 100 \mathrm{ml}$. These results are of both fundamental and practical significance since they demonstrate the magnitude of the hypocholesterolaemic action of an oil such as maize oil and also show the relative importance of restricting animal fat and introducing a hypocholesterolaemic oil in any attempt at decreasing plasma cholesterol level.

One of the main points at issue is whether or not the degree of unsaturation of the fatty acids in these fats is solely responsible for the effects observed. Although many papers have been published purporting to show that the degree of unsaturation of the fatty acids accounts for the action of fats on plasma cholesterol level, a close examination reveals a number of anomalies that are difficult to reconcile with such a hypothesis. 
Despite these inconsistencies, the thesis that increasing degree of polyunsaturation of dietary fat can be equated with increasing hypocholesterolaemic potency, and the converse, has gained such a place in scientific and lay circles that it will be difficult to modify it or to establish any other concept. There is no doubt that the nature of the triglycerides and the constituent fatty acids of fats are in part responsible for their effects on plasma cholesterol level, but our work and that of Gordon, Wilkens \& Brock ( 1958 ) demonstrate that degree of unsaturation is not the sole determinant and that certain other factors including the non-glyceride components also play a part. In experiments performed during the academic session of $1955^{-6}$ we obtained evidence that a hypercholesterolaemic factor in butter and a hypocholesterolaemic factor in maize oil could be concentrated in the relatively volatile fractions obtained by molecular distillation of these fats (Beveridge, Connell \& Mayer, 1957). Further work revealed that the cholesterol-rich distillate of butter was the most hypercholesterolaemic and that this was due at least in part to its content of cholesterol (Beveridge, Connell, Haust \& Mayer, I959). A similar result utilizing different fractionation techniques was subsequently reported for egg-yolk lipid by BronteStewart and his colleagues (Bronte-Stewart, 196I). This finding made it imperative to investigate, under more rigorous conditions than hitherto had been used, the effect of dietary cholesterol in man. This was done by adding progressively increasing amounts of cholesterol to a cholesterol-free diet providing $30 \%$ of calories from a butterfat that had been freed from this sterol by molecular distillation. We found that as the cholesterol intake was increased up to about $600 \mathrm{mg} /$ day, serum cholesterol content progressively increased, but above this intake there was essentially no further response (Beveridge, Connell, Mayer \& Haust, i960). Because of the important implications of these findings, this large-scale experiment in which over I00 volunteer subjects participated was repeated with differing amounts of supplementary cholesterol. The results of the second experiment have been plotted along with those from the first (Fig. 2). The results of the two dietary trials agreed closely. Even with daily intakes of as much as $37 \mathrm{~g}$ the response was very little greater than with an intake of about $600 \mathrm{mg}$ cholesterol/day. Indeed under the conditions used, no significant difference was noted between the results at these two levels of intake although the trend would appear to be slightly upward, going from the smaller to the larger supplement. Since most attempts to investigate the effect of dietary cholesterol in man have involved its addition to a non-vegetarian diet which already provided a daily intake of several hundred mg cholesterol, it is not surprising that dramatic increases have not been observed. An examination of the nature of the curve in Fig. 2 demonstrates clearly the reason for the apparent lack of response. It would seem redundant to say that, if one wishes to study the effect of a dietary component, the basal diet should be essentially free from the substance to be tested.

We have also examined (Beveridge, Connell $\&$ Kuksis, unpublished) the effect of dietary cholesterol in the presence of varying amounts of fat in the form of a butterfat essentially free from cholesterol. Fig. 3 shows that the addition of $800 \mathrm{mg}$ cholesterol per $950 \mathrm{kcal}$ of a fat-free diet, which on a $3000 \mathrm{kcal}$ consumption would supply about $2.5 \mathrm{~g}$ of the sterol, did not lead to a significant change in plasma cholesterol 


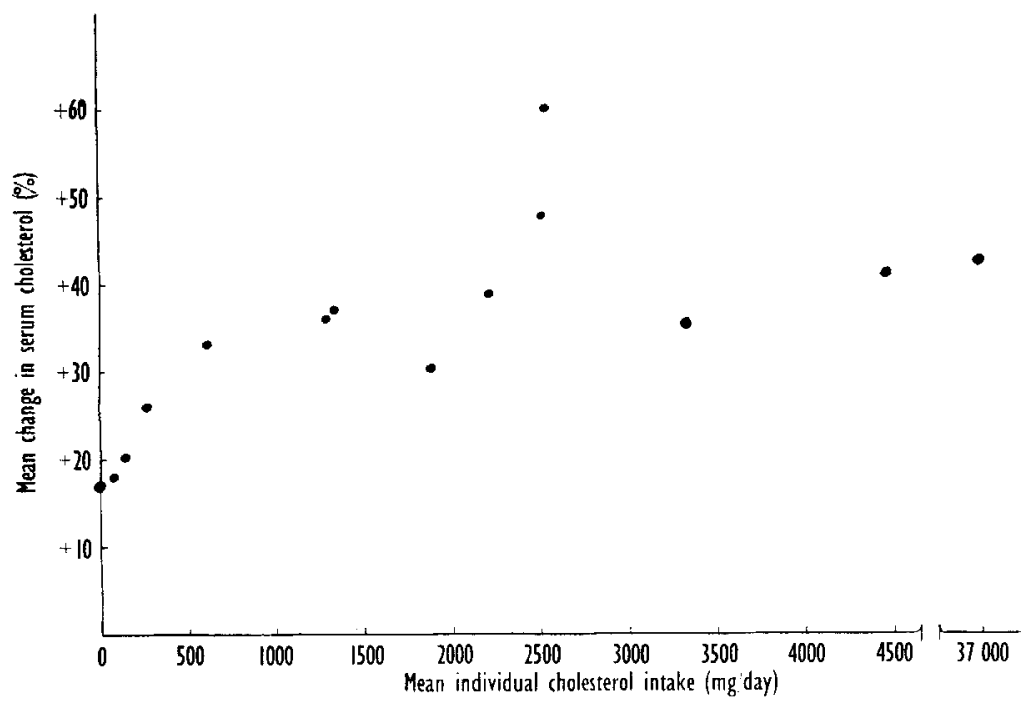

Fig. 2. Relationship between the estimated daily cholesterol intake and percentage change in serum cholesterol in groups of six to ten subjects given a diet providing $30 \%$ of the calories as a butterfat fraction stripped of cholesterol by distillation under greatly reduced pressure and of supplementation with varying amounts of cholesterol.

content. However, when cholesterol-free butterfat to supply $5 \%$ of the calories was also added, a moderate increase occurred, and when the proportion of fat calories was raised to $30 \%$, a still greater increase was observed. Wells \& Bronte-Stewart (I 963) have recently published results with similar implications concerning the importance of the fat accompanying the cholesterol.

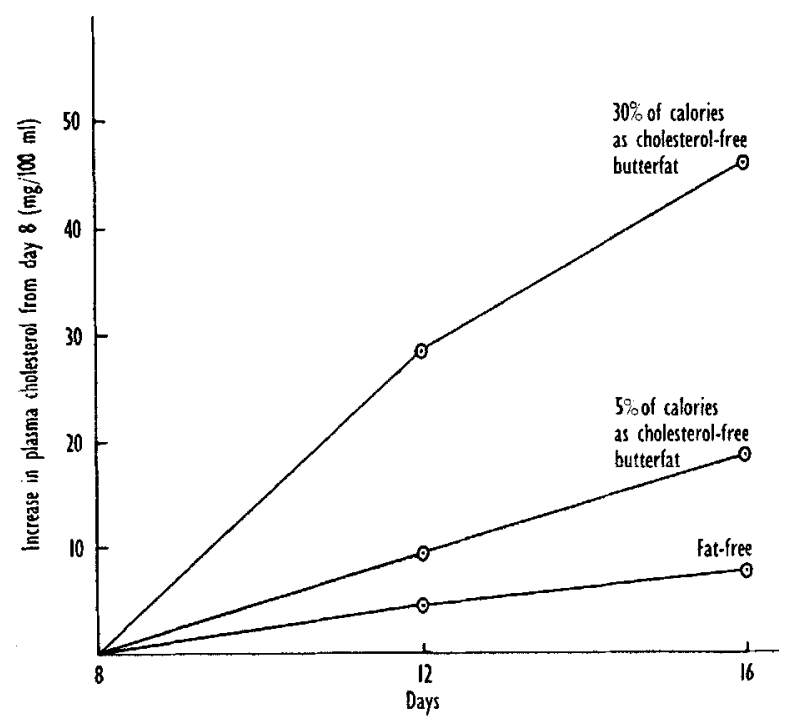

Fig. 3, Influence of the dietary level of fat on the effect of dietary cholesterol in man: university students consumed a fat-free homogenized compounded diet for 8 days. Groups of eight to ten continued for another 8 days on diets modified by the addition of $800 \mathrm{mg}$ cholesterol $/ 950 \mathrm{kcal}$. A butterfat fraction stripped of cholesterol by distillation under greatly reduced pressure was added in the amounts shown in place of an equicaloric amount of carbohydrate. 
When we first examined the effect of the butter-oil fractions on plasma cholesterol level we thought of the possibility that the concentration of the hypercholesterolaemic activity in the most volatile distillate might be due to its relatively high content of the saturated short-chain fatty acids. This possibility was investigated by incorporating into a compounded diet at a level to supply $30 \%$ of the calories a fraction of completely saturated coconut-oil triglycerides containing fatty acids of chain length $\mathrm{C}_{6}-\mathrm{C}_{12}$. Despite the absence of double bonds, this fat did not cause an increase in plasma cholesterol level when added to a fat-free diet; even when cholesterol was added, no increase in plasma sterol levels occurred (Beveridge et al. 1959). Similar findings were subsequently reported by Hashim, Arteaga \& Van Itallie (I960) and by Grande, Anderson \& Keys (196r). Another fraction of coconut-oil triglycerides with fatty acids of chain length $\mathrm{C}_{14}-\mathrm{C}_{18}$ did, however, cause an increase in plasma cholesterol levels. It may be that the difference in effect of these two triglyceride fractions is related to the route they take after absorption, medium-chain triglycerides going primarily by way of the portal vein and the long-chain triglycerides via the lymphatic circulation. It would appear therefore that degree of saturation is by no means the sole determinant of the cholesterolaemic property of fats and that chain length also must be taken into consideration. Furthermore, it may be that certain specific types of triglycerides are involved; possibly the attachment of certain acids at the $\alpha$ or $\beta$ positions may be of some importance.

In the experiments designed to throw light on the nature of the hypocholesterolaemic factors in maize oil, vitamin E, at least in the form of $\alpha$-tocopherol, was early eliminated as a possibility (Beveridge et al. 1957). Results leading to somewhat divergent conclusions were obtained in attempts to assess the role of the polyunsaturated fatty acids. For example, the introduction of a sample of hydrogenated maize oil (iodine value about 68 ) into a fat-free diet at a level of $45 \%$ of calories in place of an equicaloric amount of carbohydrate did not lead, as did the native oil, to a significant decrease in plasma cholesterol level. However, there was no difference in the decreases observed when these fat samples were substituted at a level to supply $25 \%$ of the calories for an equicaloric amount of carbohydrate in a diet providing $35 \%$ calories as butterfat (Beveridge, Connell, Mayer, \& Haust, 1958a,b). We have yet to think of a reasonable explanation for these seemingly anomalous results. Perhaps it might be appropriate to mention that certain results obtained by other workers might be similarly categorized. For example, from the elegant and rigidly controlled experiments by Ahrens and his colleagues in 1957 (Ahrens, Hirsch, Insull, Tsaltas, Blomstrand \& Peterson, 1957) findings were reported on three subjects in whom the effect of hydrogenated maize oil or cottonseed oil had been tested. In two patients greater decreases in serum cholesterol were obtained with the unhydrogenated samples, but in the third one the hydrogenated oil was just as effective as the native oil. Again when lards of widely differing iodine values, 95 and 52 , and linoleic acid contents 30.5 and $\mathrm{I} \cdot 8 \%$ were tested, there was no difference in their effects on cholesterol levels. In another experiment we found that when ethyl linoleate was added to a fat-free diet at a level to supply $30 \%$ of the calories in place of an equicaloric amount of carbohydrate, a small but significant decrease occurred in plasma 
Table I. Effect of maize oil distillates on plasma cholesterol levels in university students*

\begin{tabular}{|c|c|c|c|c|c|c|c|c|}
\hline \multirow[b]{2}{*}{$\begin{array}{c}\text { Group } \\
\text { no. }\end{array}$} & \multirow[b]{2}{*}{$\begin{array}{l}\text { Maize-oil } \\
\text { fraction }\end{array}$} & \multirow{2}{*}{$\begin{array}{c}\text { Liebermann- } \\
\text { Burchard } \\
\text { positive } \\
\text { material } \\
\text { calculated } \\
\text { as } \\
\text { sitosterol } \\
(\%)\end{array}$} & \multirow[b]{2}{*}{$\begin{array}{l}\text { No. of } \\
\text { subjects }\end{array}$} & \multicolumn{3}{|c|}{$\begin{array}{c}\text { Mean plasma cholesterol } \\
(\mathrm{mg} / \mathrm{I} 00 \mathrm{ml})\end{array}$} & & \\
\hline & & & & Day 8 & 3 Day 16 & $\begin{array}{c}\text { Difference } \\
\text { between } \\
\text { days } \\
8 \text { and } 16\end{array}$ & $t$ & $P$ \\
\hline FF & Nil & - & 16 & $134 \cdot 6$ & $136 \cdot 1$ & $+r \cdot 5$ & 0.429 & 0.5 \\
\hline I & $\begin{array}{l}\text { Distillate } \\
\text { from first } \\
10 \% \text { cut }\end{array}$ & 9.55 & I 5 & $143^{\cdot 2}$ & $I_{3} \mathbf{I} \cdot \mathbf{I}$ & $-12 \cdot 1$ & 2.820 & $0.01-0.02$ \\
\hline 2 & $\begin{array}{l}\text { Residue from } \\
\text { first } 10 \% \\
\text { cut }\end{array}$ & 0.59 & 16 & $132 \cdot 1$ & I 28.9 & $-3 \cdot 2$ & 0.514 & 0.5 \\
\hline 3 & $\begin{array}{l}\text { Residue from } \\
\text { first } \\
\text { distillation }\end{array}$ & 0.30 & I5 & $13 \mathrm{r} \cdot 6$ & 128.1 & -3.5 & 0.436 & 0.5 \\
\hline
\end{tabular}

*During the first 8 days all subjects consumed a fat-free (FF) homogenized diet. 'The maize-oil fractions were added at a level to supply $30 \%$ of the calories in place of an equicaloric amount of carbohydrate.

cholesterol level. When added in smaller amounts, $4 \mathrm{~g} / 95^{\circ} \mathrm{kcal}$, to a diet providing $40 \%$ of the calories as butterfat, no significant decrease occurred.

Other work has involved experiments with maize-oil fractions, varying widely in plant-sterol content. These were tested by substituting them for carbohydrate at a level to supply $30 \%$ of the calories in a fat-free diet. This particular level was chosen since previous experience had shown that $20 \%$ of calories as maize oil under the conditions used by us did not exert a significant hypocholesterolaemic effect and we had to add maize oil to supply $40 \%$ or more of the calories to elicit a clearly demonstrable action. Table I shows that only the fraction rich in plant sterol brought about a significant fall. We then performed an experiment in which a sitosterol preparation was incorporated at varying levels into a diet providing $45 \%$ of the calories as butterfat. Fig. 4 shows that at a level of 50 , 100 , or $200 \mathrm{mg}$ sitosterol $/ 950 \mathrm{kcal} \mathrm{no}$ change was brought about, but at the $300 \mathrm{mg}$ level and above there occurred progressively greater decreases. One of the values would appear to be out of order and we have no explanation to offer other than that it may be an embarrassing example of biological variation. The important point to note here is that with a supplement of sitosterol amounting to only $300 \mathrm{mg} / 950 \mathrm{kcal}$ which, on a $3000 \mathrm{kcal}$ intake, would supply a little less than $\mathrm{I} g$ of the plant sterol daily, a significant decrease in plasma cholesterol level occurred. Since it would take only about roo g maize oil to supply this amount of plant sterol, we would maintain that this non-glyceride component accounts at least in part for the hypocholesterolaemic action of this and similar oils.

In the light of these results it is apparent that in addition to the nature of the fatty acid residues, having in mind both chain length and degree of unsaturation and possibly the precise constitution of the triglycerides, the non-glyceride portions of food fats must also be taken into consideration in devising diets for the control of serum lipid levels. 


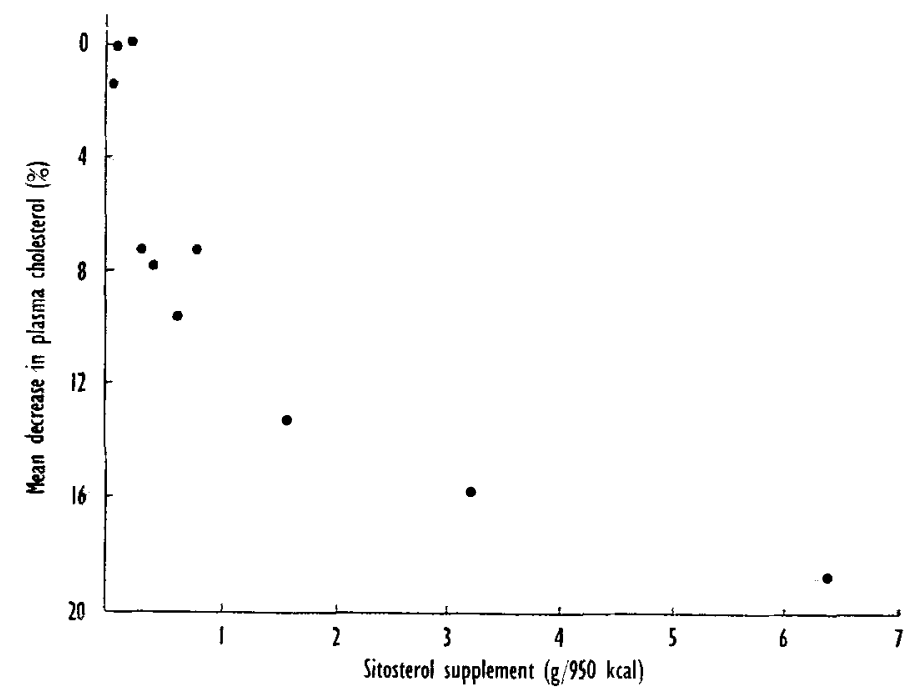

Fig. 4. Relationship between the level of sitosterol supplementation and percentage change in plasma cholesterol in ten groups of subjects each comprised of eight to nine university students who subsisted for 16 days on a homogenized compounded diet providing $45 \%$ of calories as butterfat. The sitosterol supplement was added to the diet on day 8 .

The nutrient interrelationships of fatty acids and proteins offer the same or even greater difficulties of interpretation as those mentioned on p. 19. For example, plant and animal protein foods usually have associated with them plant sterols and cholesterol respectively, and also triglycerides which may themselves have variable effects (Kinsell et al. 1952; Kinsell, Michaels, Friskey \& Splitter, r 958; Ahrens, Blankenhorn \& Tsaltas, 1954; Ahrens et al. 1957; Beveridge, Connell, Mayer, Firstbrook \& DeWolfe, 1954; Bronte-Stewart, Antonis, Eales \& Brock, 1956). It is obvious that, unless purified protein sources are used in conjunction with a basal

Table 2. Effects on plasma cholesterol level in young male subjects of the addition or withdrawal of calcium caseinate for equicaloric amounts of maltose-dextrins in a basal diet providing $15 \%$ of the calories as protein*

\begin{tabular}{|c|c|c|c|c|c|c|c|c|}
\hline \multirow[b]{2}{*}{$\begin{array}{c}\text { Group } \\
\text { no. }\end{array}$} & \multirow[b]{2}{*}{$\begin{array}{l}\% \text { calories } \\
\text { as protein }\end{array}$} & & \multicolumn{3}{|c|}{$\begin{array}{l}\text { Mean plasma cholesterol } \\
(\mathrm{mg} / 100 \mathrm{ml})\end{array}$} & & \multirow{2}{*}{\multicolumn{2}{|c|}{$P$}} \\
\hline & & $\begin{array}{l}\text { No. of } \\
\text { subjects }\end{array}$ & Day & Day 16 & $\begin{array}{c}\text { Difference } \\
\text { between } \\
\text { days } \\
8 \text { and } 16\end{array}$ & $t$ & & \\
\hline I & 25 & 6 & I 57.3 & $154^{\circ} 0$ & $-3 \cdot 3$ & $\mathrm{I} \cdot 14$ & 0.3 & -0.4 \\
\hline 2 & 20 & 6 & 149.6 & 146.6 & -3.0 & 0.40 & 0.7 & -0.8 \\
\hline 3 & 15 & 7 & 162.8 & 162.4 & -0.4 & 0.09 & & 0.9 \\
\hline 4 & 10 & 7 & I 65.9 & $171 \cdot 2$ & $+5 \cdot 3$ & $\mathrm{r} \cdot 5^{8}$ & 0.1 & -0.2 \\
\hline 5 & 5 & 7 & 152.0 & $171 \cdot 1$ & $+19^{\circ} \mathbf{I}$ & 3.04 & 0.0 & $2-0.05$ \\
\hline
\end{tabular}

*All subjects ate the basal diet providing $15 \%$ of calories as protein for 8 days before the change in dietary protein to the levels given in column 2 . 
diet of constant composition, it is hazardous to attribute any changes observed to alterations in dietary protein. Table 2 shows the results obtained by varying the protein level for subjects who had been eating a diet in which protein supplied $15 \%$ of the calories. The only change observed was that those who were transferred to a diet low in protein showed an increase in plasma cholesterol. It is of interest to recall that Mann and co-workers have found for the rat and monkey that low-protein diets especially with added cholesterol cause an increase in serum cholesterol which can be largely prevented by the addition of the sulphur-containing amino acids, methionine and cystine (Mann, Andrus, McNally \& Stare, I953; Fillios \& Mann, I954; Mann, 1960). Although it seemed almost inconceivable that a deficiency of these substances could be induced in short-term experiments such as ours, we carried out a feeding trial to determine this point. We found that the increase in plasma cholesterol seen in male subjects transferred to a diet low in protein could be prevented by adding the amount of methionine and cystine supplied by the additional protein in the basal diet (see Table 3). Man would therefore appear to respond in the same way as the rat and the cebus monkey to the dietary conditions described here.

Table 3. Fffect of methionine and cystine in preventing an increase in plasma cholesterol level in young male subjects transferred from a compounded diet providing ${ }_{1} 5 \%$ of the calories as protein to one supplying $5 \%$ *

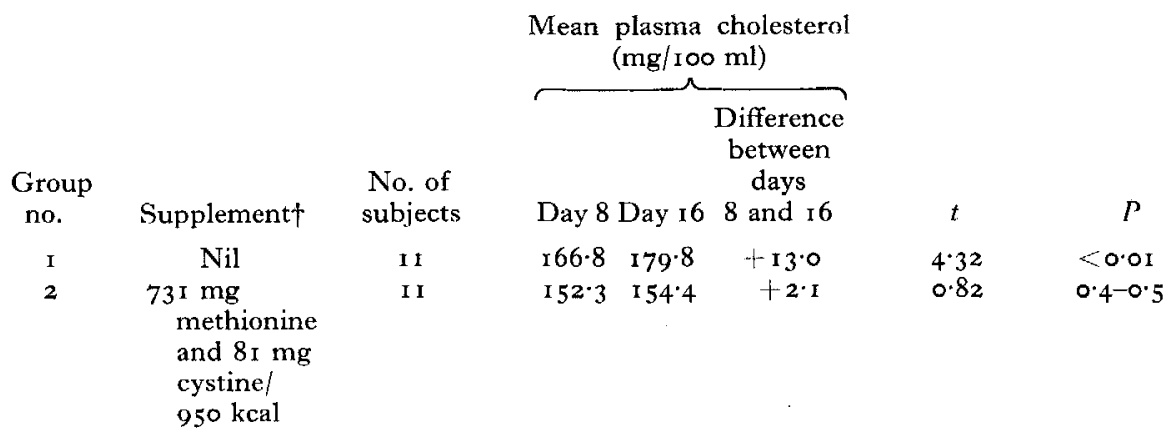

\footnotetext{
*All subjects ate the basal diet providing $15 \%$ of the calories as protein for 8 days before the change in dietary protein.

tQuantities of methionine and cystine contained in the calcium caseinate omitted from the basal diet to lower the protein level from $15 \%$ to $5 \%$ of calories.
}

An additional feature that we tested was the possibility that the type of dietary fat might exert some effect on the response of man to a diet low in protein. It was found that when maize oil was used in place of butterfat in the basal diet there was no increase in plasma cholesterol when subjects were transferred from the diet providing $15 \%$ of the calories as protein to one providing $5 \%$. It is suggested that the amount of cholesterol in the butterfat was such as to account for the increase seen with the low-protein diet, whereas the plant sterols and triglycerides of the maize oil presumably combined to inhibit the tendency for increased plasma cholesterol levels to occur on the low-protein diet. A further feature might be that with maize 
oil more of the bile acid conjugation might take place with glycine than with taurine, thus sparing the supply of the sulphur-containing amino acids. To date, there is no good evidence that it is so. In a series of experiments, however, performed in collaboration with Dr Bruce Gordon and Dr Kuksis on a young male subject in a metabolic ward, we did note that the lowest glycine-taurine ratios were observed with a diet containing maize oil. Further work must be done to establish whether there is in fact any significant change in the conjugation of bile acids under these experimental conditions.

In conclusion it seems scarcely necessary to add, in the light of the material I have presented in this paper, that much remains to be discovered concerning the nutrient interrelationships of the fatty acids. We know essentially nothing of the effects, beneficial or otherwise, of high intakes of single fatty acids. The report by Stetten $\&$ Salcedo (1945) of the effect of large amounts of dietary ethyl laurate on the development of cardiac necrosis in rats is presumably one example of fatty acid imbalance that can be extremely harmful. There may be many others. Presumably as long as man obtains his intake of dietary fat from a variety of sources, he need have little fear of developing this type of a fatty acid imbalance.

I am indebted to Dr H. L. Haust, Department of Biochemistry, Queen's University, Kingston, Ont., for his assistance in the preparation of the manuscript and for his constructive criticism.

\section{REFERENCES}

Aaes-Jørgensen, E. (196I). Physiol. Rev. 41, I.

Aaes-Jørgensen, E. \& Holman, R. T. (1958). F. Nutr. 65, 633 .

Ahrens, E. H. Jr., Blankenhorn, D. H. \& Tsaltas, T. T. (1954). Proc. Soc. exp. Biol., N.Y., 86, 872.

Ahrens, E. H. Jr., Hirsch, J., Insull, W. Jr., Tsaltas, 'T. T., Blomstrand, R. \& Peterson, M. L. (I957). Lancet, i, 943 .

Beveridge, J. M. R., Connell, W. F., Haust, H. L. \& Mayer, G. A. (1959). Canad. F. Biochem. $37,575$.

Beveridge, J. M. R., Connell, W. F. \& Mayer, G. A. (1956). Canad. Y. Biochem. 34, 44I.

Beveridge, J. M. R., Connell, W. F. \& Mayer, G. A. (1957). Canad. Y. Biochem. 35, 257.

Beveridge, J. M. R., Connell, W. F., Mayer, G. A., Firstbrook, J. B. \& DeWolfe, M. S. (1954). Circulation, 10, 593.

Beveridge, J. M. R., Connell, W. F., Mayer, G. A. \& Haust, H. L. (1958a). Canad. F. Biochem. 36, 895.

Beveridge, J. M. R., Connell, W. F., Mayer, G. A. \& Haust, H. L. (1958b). Fed. Proc. 17, 470.

Beveridge, J. M. R., Connell, W. F., Mayer, G. A. \& Haust, H. L. (r96o). F. Nutr. 7I, 6r.

Bronte-Stewart, B. (1961). Fed. Proc. 20, no. 1, p. 127.

Bronte-Stewart, B., Antonis, A., Eales, L. \& Brock, J. F. (1956). Lancet, i, 52 I.

Buchanan, A. A. (1960). Biochem. F. 75, 3 I5.

Dhopeshwarkar, G. A. \& Mead, J. F. (1962). Proc. Soc. exp. Biol., N.Y., 109, 425.

Fillios, L. C. \& Mann, G. V. (I954). Metabolism, 3, I6.

Gordon, H., Wilkens, J. \& Brock, J. F. (1958). Lancet, ii, 244.

Grande, F., Anderson, J. T. \& Keys, A. (196r). F. Nutr. 74, 420.

Greenberg, I. D. \& Moon, H. D. (I 961). Arch. Biochem. Biophys. 94, 405.

Hashim, S. A., Arteaga, A. \& Van Itallie, T. B. (I960). Lancet, i, I I05.

Hauge, J. G. \& Nicolaysen, R. (I959), Acta physiol. scand, 45, 19.

Holman, R. T. \& Peifer, J. J. (r960). F. Nutr. 70, 4 I I.

Horwitt, M. K. (1 960). Amer. F. clin. Nutr. 8, 451.

Hove, E. L. \& Harris, P. L. (1946). F. Nutr, 3I, 699.

James, A. T., Lovelock, J. E. \& Webb, J. P. W. (r959). Biochem. F. 73, ro6.

Johnston, P. V., Kopaczyk, K. C. \& Kummerow, F. A. (196r). F. Nutr. 74, 96.

Kinsell, L. W., Michaels, G. D., Friskey, R. W. \& Splitter, S. (1958). Lancet, i, 334.

Kinsell, L. W., Partridge, J., Boling, L., Margen, S. \& Michaels, G. D. (1952). F. clin. Endocrin. 12, 909. 
Kirschman, J. C. \& Coniglio, J. G. (1961). F. biol. Chem. 236, 2200.

McLean, J. R. \& Beveridge, J. M. R. (1952), F. Nutr. 47, 4 I.

Mann, G. V. (1960). Fed. Proc. 19, 15.

Mann, G. V., Andrus, S. B., McNally, A. \& Stare, F. J. (1953). Y. exp. Med. 98, 195.

Marks, P. A., Gellhorn, A. \& Kidson, C. (1960). F. biol. Chem. 235, 2579.

Mead, J. F. (1960). Amer. F. clin. Nutr. 8, 55.

Nunn, L. C. A. \& Smedley-MacLean, I. (1938). Biochem. F. 32, 2178.

Schwarz, K., Bieri, J. G., Briggs, G. M. \& Scott, M. L. (1957). Proc. Soc. exp. Biol., N.Y., 95, 621.

Söderhjelm, L. (1962). F. Nutr. 78, 438 .

Stetten, DeW. Jr. \& Salcedo, J. Jr. (I945). F. Nutr. 29, I67.

Valberg, L. S., Young, R. A. \& Beveridge, J. M. R. (1959). Canad. J. Biochem. 37, 493.

Wells, V. M. \& Bronte-Stewart, B. (1963). Brit. med. Y. i, 577.

Williams, M. A. \& Scheier, G. E. (เ96I). F. Nutr. 74, 9 .

Witten, P. W. \& Holman, R. T. (1952). Arch. Biochem. Biophys. 4I, 266.

27 Fuly, Second Session

Chairman : Professor George H. Beaton, PhD, Department of Nutrition, School of Hygiene, University of Toronto

\title{
Interrelationships of nutrients: Chairman's opening remarks
}

\author{
By G. H. Beaton, Department of Nutrition, School of Hygiene, University of Toronto, \\ Toronto, Canada
}

The study of nutrient interrelationships is not new. However, in recent years it has gained added impetus. There are many reasons for this added interest--and many reasons for added concern about possible nutrient antagonisms. Miller \& Payne (I964) have discussed some of the factors affecting nitrogen balance and Blaxter (1964) has reviewed the work on factors affecting energy utilization. Both of these fields have obvious application in the developing areas of the world and are of immediate concern. They are also of great economic importance in animal husbandry. Recent interest in lipid metabolism and the association of abnormalities of lipid metabolism with coronary atherosclerosis has led us into the field of interrelationships between fat, fatty acids and other dietary components. Widespread institution of food enrichment programmes is another reason for concern.

For many years it has been recognized that interrelationship also existed between the vitamins and other micro-nutrients. This was intensively studied during the era of vitamin discoveries. However, owing to the poor definition of dietary constituents, many of the early results were difficult to interpret. When purified, semi-synthetic diets were available, attention changed to a study of the functions of individual vitamins and interest in interrelationships lagged, with a few notable exceptions. The cycle is now repeating itself and again we are showing great interest in these interrelationships.

When we deal with the micro-nutrients and particularly with the vitamins, we face certain problems that are not as pressing when protein or energy metabolism is being studied. One of the major problems we face, and I am sure that Dr Campbell will 